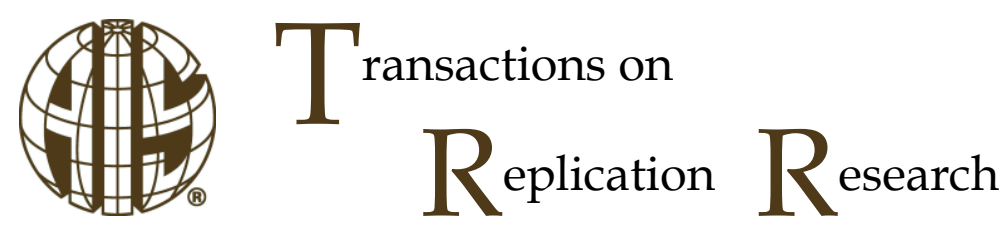

\title{
Mitigating Turnover Intentions: Are All IT Workers Warriors?
}

\author{
Deborah J. Armstrong \\ Business Analytics, Information Systems \& Supply \\ Chain, Florida State University \\ djarmstrong@business.fsu.edu \\ Mari W. Buche \\ Management Information Systems, Michigan \\ Technological University \\ mwbuche@mtu.edu
}

\author{
Cynthia K. Riemenschneider \\ Management Information Systems, Baylor University \\ C_Riemenschneider@baylor.edu \\ Kenneth R. Armstrong \\ Business Analytics, Information Systems \& Supply \\ Chain, Florida State University \\ karmstrong2@business.fsu.edu
}

\begin{abstract}
:
The current study is a conceptual replication of Ahuja, Chudoba, Kacmar, McKnight, and George's (2007) model of the proximal and distal antecedents of the turnover intentions of information technology (IT) professionals. Whereas the original study focused on 'IT Road Warriors', those that spend most of their work life away from home; we applied the original study's hypotheses and model to the more general context of IT professionals. Results from a sample of 301 IT professionals housed in an on-site internal IT department were mixed. Consistent with Ahuja et al. (2007), the relationships between exhaustion, organizational commitment, and turnover intention were supported. Also, the influence of work-family conflict on exhaustion, but not organizational commitment, was confirmed. In contrast to Ahuja et al. (2007), the replication study found that fairness of rewards was much more important to in-house IT professionals than autonomy. Future research should investigate the boundaries of Ahuja et al.'s (2007) model of turnover intention for various sub-populations within the IT profession, such as system administrators, contract workers, and perhaps CIOs. Researchers may also want to explore factors outside the current model that may impact the turnover intention of IT professionals such as organizational and professional identity and boundary spanning.
\end{abstract}

Keywords: Turnover Intention, Replication, IT Personnel

The manuscript was received 07/27/2017 and was with the authors one month for one revision.

\section{Introduction}

The turnover of information technology (IT) professionals continues to create challenges for employers not only in terms of the staffing costs, but also workforce stability (Lo, 2014; Luftman \& Kempaiah, 2007; Purohit, 2016). Identifying the key factors that contribute to the turnover intention (TOI) of IT professionals has been studied in various contexts for over two decades. In general, researchers have sought to identify the salient antecedents (e.g., Igbaria \& Greenhaus, 1992) in order to potentially inform practitioners on best practices to retain valuable knowledge workers while increasing academic understanding of this phenomenon. A sample of the most common constructs identified as relevant antecedents include work-family conflict (e.g., Adams, King, \& King, 1996), perceived work overload (e.g., Moore, 2000), work exhaustion (e.g., Moore, 2000), job autonomy (e.g., Beehr, 1976), organizational commitment (e.g., Tsui, Pearce, Porter, \& Tripoli, 1997), fairness of rewards (e.g., Cropanzano, Rupp, \& Byrne, 2003), and other job characteristics such as task fit (e.g., Hackman \& Oldham, 1975).

In their original study, Ahuja, Chudoba, Kacmar, McKnight, and George (2007) focused on the turnover intentions of IT Road Warriors, those IT workers who are predominantly performing their tasks at client firms that are often located out of town (Madden, 1995). Extending Moore's (2000) research on work exhaustion and TOI, Ahuja at al.'s (2007) findings identified the importance of exploring TOI within the context and role

$$
\begin{array}{llll}
\text { Volume } 4 & \text { Paper } 10 & \text { pp. } 1-20 & \text { September } 2018
\end{array}
$$


of IT Road Warriors. This research demonstrated that IT employees' work setting and predominant task structure significantly influences both the direct and mediated effects of key antecedents on TOI (see Figure 1).

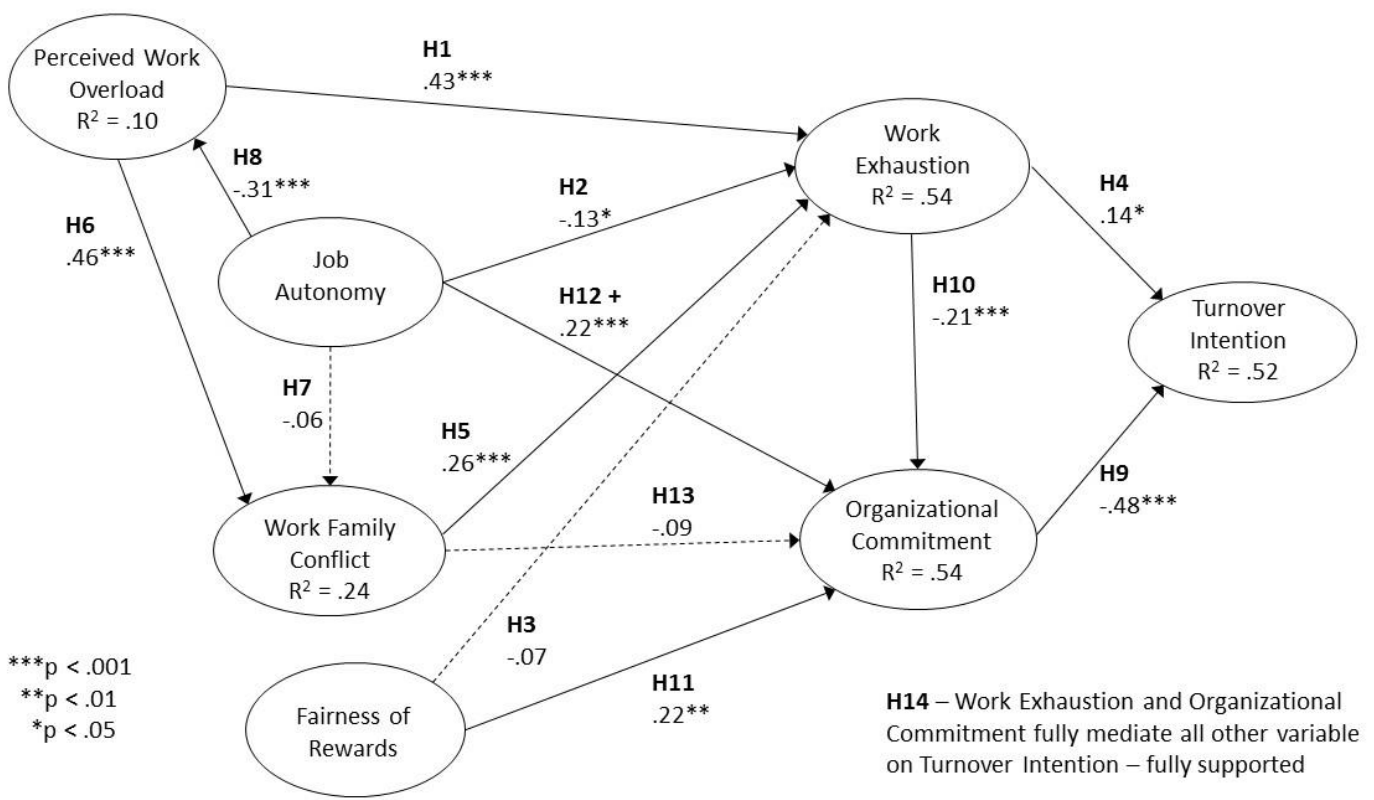

Figure 1. Research Hypotheses and Results from Original Study (Ahuja et al., 2007)

The original study provided meaningful contributions for practitioners and researchers; the citation count reported via the Web of Science database, as of December 31, 2017, was just over 120. For organizations, the findings indicated that supervisors should be cognizant of challenges posed by the physical separation from the parent company and from the individual's social / family network (i.e. IT Road Warriors spend four days at the client location and three days at home). Specifically, work family conflict (WFC) was shown to influence work exhaustion for IT Road Warriors and, indirectly, organizational commitment (Ahuja et al., 2007). These IT workers are immersed in the clients' physical location and work independently with little direct supervision. While the preponderance of hypotheses were supported, the unsupported hypotheses in the original study were those that involved job autonomy, WFC, and fairness of rewards as dependent variables. This replication study is interested in testing whether or not similar results might exist for in-house IT professionals (i.e., IT professionals who support clients and projects within a firm).

Turnover continues to be a major concern for companies with substantial IT requirements. Both Moore (2000) and Ahuja et al. (2007) call for additional research on TOI, and suggest a focus on investigating this phenomenon in a variety of IT work settings. We have performed a conceptual replication of Ahuja et al.'s (2007) IT Road Warrior study, analyzing the TOI of in-house IT professionals at a large food-processing company in the Midwestern United States. We wanted to test the boundaries of the model through the evaluation of the antecedents of TOI in a completely different context than provided in the original study. We have included the same constructs in the replication as found in the original study (Figure 1), and adopted identical hypotheses. As a conceptual replication, we used different measures for key variables to explore any idiosyncratic features of the original item wording, and test the strength of the key relationships within a different context.

\section{Method}

Similar to the original study, we focused on IT employees at a large company. Our sample came from an organization in the food processing industry, with over 100,000 employees worldwide. Of these, approximately 9,000 work at the corporate headquarters located in the Midwestern United States where the main corpus of IT employees is located. In contrast to the original study in which the respondents were all 
Road Warriors (work from home or at client sites), $79 \%$ of the 554 IT employees in the participating company were located at the corporate headquarters, $21 \%$ were located at another corporate facility and $100 \%$ of the IT employees served internal clients (i.e., other functional areas).

An initial email containing the survey instrument was sent to all 554 employees from one of the researchers, and the employees were guaranteed anonymity. Two follow-up emails were sent over the next 2 weeks to encourage participation. An analysis of 1) late responder surveys versus early responder surveys and 2) complete surveys versus incomplete surveys was completed to determine if nonresponse bias existed; none was found. Of the 554 individuals contacted, 362 completed the instrument for a $65 \%$ response rate. Demographics of the sample are shown in Table 1. Of the 362 completed surveys, 60 were removed because of incomplete data, and one outlier (received 15 raises in three years) leaving a total of 301 usable responses. Of the respondents, $50 \%$ were male with $10 \%$ indicating female and the remainder chose not to respond to the gender question. The participants had a mean organizational tenure of 9.4 years, and job tenure of 3.1 years. Unlike the original study, we did not collect data on respondent age because previous research has asserted that age and organizational tenure are highly correlated (Lin \& Hsieh, $2002 ; \mathrm{Ng} \&$ Feldman, 2010) and thus redundant. We also did not collect marital status because it was non-significant in the original study and we felt not salient for the replication study sample.

\begin{tabular}{|c|c|c|}
\hline \multicolumn{3}{|c|}{ Table 1. Sample Demographics } \\
\hline \multicolumn{3}{|l|}{ Total Responses: 301} \\
\hline \multirow[t]{3}{*}{ Gender } & Male & $49.8 \%$ \\
\hline & Female & $10.0 \%$ \\
\hline & Unidentified & $40.2 \%$ \\
\hline \multirow[t]{5}{*}{ Tenure at Company } & $<2$ years & $17.9 \%$ \\
\hline & 2 - 5 years & $16.3 \%$ \\
\hline & $6-10$ years & $24.9 \%$ \\
\hline & $11-15$ years & $20.3 \%$ \\
\hline & $>15$ years & $20.6 \%$ \\
\hline \multirow[t]{5}{*}{ Tenure in Job } & $<1$ year & $25.6 \%$ \\
\hline & $1-2$ years & $28.9 \%$ \\
\hline & 3 - 5 years & $23.3 \%$ \\
\hline & $>5$ years & $16.9 \%$ \\
\hline & Undefined & $5.3 \%$ \\
\hline \multirow[t]{5}{*}{ Number of Raises } & 0 & $31.9 \%$ \\
\hline & 1 & $26.6 \%$ \\
\hline & 2 & $16.3 \%$ \\
\hline & 3 & $12.6 \%$ \\
\hline & $>3$ & $12.5 \%$ \\
\hline \multirow[t]{6}{*}{ Income } & $<=\$ 54,999$ & $15.3 \%$ \\
\hline & $\$ 55,000-\$ 69,999$ & $13.6 \%$ \\
\hline & $\$ 70,000-\$ 84,999$ & $23.3 \%$ \\
\hline & $\$ 85,000-\$ 99,999$ & $26.2 \%$ \\
\hline & $>=\$ 100,000$ & $18.6 \%$ \\
\hline & Unidentified & $3.0 \%$ \\
\hline
\end{tabular}


The questionnaire items were taken from existing scales and are listed in Appendix A (See Table A1). Table 2 shows the construct measures used in the original study and this replication, both those that were changed and those that were retained. Because fairness of rewards, job autonomy, and work-family conflict are less frequently studied concepts in the IT turnover intention literature, we decided to use different measures to ensure there was nothing idiosyncratic about the items. With regard to fairness of rewards, the replication study used McKnight, Phillips, and Hardgrave's (2009) measure of structural fairness, which included two items from Moore (2000) and three items developed to capture the teamoriented nature of IT work; whereas the original study's measure was more focused on process and procedural equity. With regard to job autonomy, while the replication study did not use the identical measure as Moore (2000), the same conceptualization of autonomy as "input in decision making" was utilized; Ahuja et al. (2007) used a measure of job autonomy with more of a control focus to reflect "how, when and what work is done" (p. 8). For work-family conflict, we assert that the measures from the two studies tap into the same concept, but have slightly different wording in their items. Both measures assessed how one's job causes stress/strife outside the work environment (home and family). Finally, while the authors of the two organizational commitment scales are different, there is a significant amount of overlap in the items. The replication study included four of the five items that were included in the original study. In addition to the four 'common' organizational commitment items, the replication study also included four items focused on positive speech to others about the organization.

\begin{tabular}{|l|l|l|}
\hline \multicolumn{2}{|c|}{ Table 2. Measures } \\
\hline Measure & Original Study & Replication Study \\
\hline Job Autonomy & Beehr, 1976 (4 items) & McKnight et al., 2009 (4 items) \\
\hline Work-Family Conflict & Adams et al., 1996 (5 items) & Thomas \& Ganster, 1995 (8 items) \\
\hline Organizational Commitment & Tsui et al., 1997 (5 items) & Wayne, Shore, \& Liden, 1997 (7 items) \\
\hline Work Exhaustion & Moore, 2000 (4 items) & Moore, 2000 (4 items) \\
\hline Perceived Work Overload & Moore, 2000 (4 items) & Moore, 2000 (2 items) \\
\hline Fairness of Rewards & Developed (4 items) & McKnight et al., 2009 (5 items) \\
\hline Turnover Intention & Moore, 2000 (4 items) & Moore, 2000 (4 items) \\
\hline
\end{tabular}

\section{Results}

\subsection{Methodological Differences}

While the replication study was conducted as a conceptual replication of the original study, it is important to note that there were a few differences between the methods employed in the two studies. For example, in the original study the authors used reverse-scored items and statistical tests in LISREL (Widaman, 1985; Williams, Cote, \& Buckley, 1989) to measure common method variance; the replication study used reversescored items, statistical tests in SPSS and PLS (Podsakoff, MacKenzie, Lee, \& Podsakoff, 2003), and took an additional step in the design of the survey by adding a marker variable to address common method bias (Lindell \& Whitney, 2001). In addition, in the original study the item OrgCom1 was removed due to low loadings; whereas in the replication study items OrgCom1, OrgCom2, Fairness5, and WFC1 were removed. Finally, while both studies used partial least squares for data analysis, the original study used 100 resamples in the bootstrapping process, and the replication study used 5,000 resamples. The details of the data analysis for the replication study follow.

\subsection{Response Bias and Common Method Variance Testing}

Response bias was assessed using the Armstrong and Overton (1977) procedure. The sample was divided into three segments: early, middle and late responders. An analysis of variance comparing the early and 
late responders indicated a nonsignificant difference for all of the demographic variables and the dependent variable (TOI).

To address potential common-method bias in the survey design, we included reverse-scored items to reduce compliance problems (Lindell \& Whitney, 2001). We assessed the extent of common-method variance $(\mathrm{CMV})$ in the data with three tests. First, we performed Harmon's one factor test (Podsakoff \& Organ, 1986) by including all of the items in a principal components factor analysis. The results revealed seven factors, with no single factor accounting for a majority of variance (i.e. the largest factor variance was $30.4 \%$ ), suggesting no substantial CMV among the scales. We then followed the procedure recommended by Podsakoff, MacKenzie, Lee, and Podsakoff (2003), which specifies that, in addition to theoretical constructs, a common-method construct (that includes all the indicators) be used in the empirical research model. We assessed the variance explained by the common-method construct relative to the variance explained by the substantive constructs. As shown in Appendix A, Table A2, the average variance explained by the substantive constructs was 0.58 , while the average variance explained by the common-method construct was 0.05 . Finally, we used a theoretically unrelated construct (social need strength) as a marker variable (Lindell \& Whitney, 2001). The largest shared variance (work exhaustion and social need strength) was 0.023 . Taken together, these analyses indicate that common-method bias did not significantly affect our results. Partial least squares (PLS) was used for data analysis using a two-step approach. First, the measurement model was evaluated to assess the validity and reliability of the measures, then the structural model was evaluated to assess the hypotheses.

\begin{tabular}{|c|c|c|c|c|c|c|c|c|c|c|}
\hline Variable & Mean & Std & ICR & 1 & 2 & 3 & 4 & 5 & 6 & 7 \\
\hline 1. Work-Family Conflict & 3.51 & 1.43 & .95 & .73 & & & & & & \\
\hline 2. Job Autonomy & 4.97 & 1.31 & .93 & -.03 & .78 & & & & & \\
\hline 3. Work Overload & 4.55 & 1.52 & .94 & $.57^{\star \star}$ & -.04 & .89 & & & & \\
\hline 4. Work Exhaustion & 3.73 & 1.58 & .94 & $.60^{\star *}$ & $-.17^{\star \star}$ & $.60^{\star *}$ & .78 & & & \\
\hline $\begin{array}{l}\text { 5. Organizational } \\
\text { Commitment }\end{array}$ & 4.94 & 1.27 & .94 & $-.30^{\star *}$ & .05 & $-.16^{\star *}$ & $-.34^{\star *}$ & .75 & & \\
\hline 6. Fairness of Rewards & 4.53 & 1.32 & .87 & $-.38^{* *}$ & $.16^{\star *}$ & $-.28^{\star *}$ & $-.38^{\star *}$ & $.33^{* *}$ & .63 & \\
\hline 7. Turnover Intention & 2.83 & 1.44 & .93 & $.20^{\star \star}$ & $-.12^{*}$ & $.14^{*}$ & $.34^{\star *}$ & $-.53^{\star \star}$ & $-.32^{\star \star}$ & .78 \\
\hline \multicolumn{11}{|c|}{$\begin{array}{l}\text { Average variance extracted (AVE) is in bold on the diagonal } \\
\text { Internal composite reliability (ICR) } \\
\text { Sianificance of correlations: }{ }^{* *} \mathrm{D}<.01{ }^{*} \mathrm{D}<.05\end{array}$} \\
\hline
\end{tabular}

(Table continued on next page) 


\begin{tabular}{|c|c|c|c|c|c|c|c|c|}
\hline \multicolumn{9}{|c|}{ Table 3. Descriptives, Correlations, and Measurement Model Statistics - Continued } \\
\hline Variable & Mean & Std & ICR & 8 & 9 & 10 & 11 & 12 \\
\hline 1. Work-Family Conflict & 3.51 & 1.43 & .95 & $.13^{*}$ & -.01 & -.01 & .06 & $.22^{* *}$ \\
\hline 2. Job Autonomy & 4.97 & 1.31 & .93 & .09 & .03 & .01 & .05 & $.21^{\star \star}$ \\
\hline 3. Work Overload & 4.55 & 1.52 & .94 & .06 & .02 & -.01 & -.04 & $.13^{*}$ \\
\hline 4. Work Exhaustion & 3.73 & 1.58 & .94 & .06 & .02 & -.02 & .06 & .09 \\
\hline 5. Organizational Commitment & 4.94 & 1.27 & .94 & -.06 & -.06 & -.01 & .06 & -.09 \\
\hline 6. Fairness of Rewards & 4.53 & 1.32 & .87 & -.05 & -.03 & .03 & -.01 & .02 \\
\hline 7. Turnover Intention & 2.83 & 1.44 & .93 & -.07 & -.04 & -.01 & -.11 & -.02 \\
\hline 8. Organizational Tenure & 9.37 & 7.35 & 1.00 & 1.00 & $.41^{* *}$ & $.13^{*}$ & .01 & $.46^{\star \star}$ \\
\hline 9. Job Tenure & 3.13 & 4.44 & 1.00 & & 1.00 & .01 & $-.15^{\star *}$ & .09 \\
\hline 10. Gender & $\mathrm{n} / \mathrm{a}$ & $\mathrm{n} / \mathrm{a}$ & 1.00 & & & 1.00 & .09 & $.15^{\star \star}$ \\
\hline 11. Number of Raises & 1.45 & 1.87 & 1.00 & & & & 1.00 & .08 \\
\hline 12. Salary & $\mathrm{n} / \mathrm{a}$ & $\mathrm{n} / \mathrm{a}$ & 1.00 & & & & & 1.00 \\
\hline \multicolumn{9}{|c|}{$\begin{array}{l}\text { Average variance extracted (AVE) is in bold on the diagonal } \\
\text { Internal composite reliability (ICR) }\end{array}$} \\
\hline
\end{tabular}

\subsection{Measurement Model}

Means, standard deviations, reliability measures, average variance extracted (AVE) and correlations for the variables are shown in Table 3. A confirmatory factor analysis was conducted (see Table 4). Due to low factor loadings two items were dropped (Fairness5, WFC1) and two items were dropped because they loaded on a separate factor (OrgCom1, OrgCom2). The lowest reliability in Table 3 is 0.87 (fairness of rewards), which is well above the accepted level of 0.70 (Fornell \& Larcker, 1981). For convergent validity, we note that the AVE's were all above 0.50 (Chin, 1998) with the lowest AVE of 0.63 (fairness of rewards), indicating that the items for each measure did converge.

Discriminant validity was assessed using the Fornell and Larcker (1981) test. Each latent variable correlation should be less than the square root of the AVE of that variable. Not only did our data meet this requirement, it also passed the more stringent test that the correlation be less than the AVE itself as Table 3 shows (See Appendix A, Tables A3 and A4 for the comparative descriptive statistics). It is interesting to note that there were significant differences in the means of the two samples on five of the constructs: work-family conflict, work overload, organizational commitment, organizational tenure, and number of raises. The difference in the organizational commitment means (5.29 - original, 4.94 - replication) indicates that the Road Warriors had more organizational commitment than the in-house IT personnel and over three times the number of raises as the in-house IT personnel (4.69 - original, 1.45 - replication). In contrast, the years with the organization was significantly higher for in-house IT personnel (1.8 - original, 9.37 - replication), but the TOI of both groups was not statistically different (2.55 - original, 2.83 - replication). In summary, the measures demonstrated adequate construct validity and thus we proceed to the structural model.

\subsection{Structural Model}

Figure 2 graphically represents the results of the structural model test. We used the PLS bootstrapping technique with 5,000 resamples and 300 cases (Chin, 2001). Consistent with the original study, control variables were entered as predictors of turnover intention, organizational commitment, and work exhaustion. The variables in the model explained $33 \%$ of the variance in work-family conflict with perceived work overload as the main driver. The variables explained $51 \%$ of the variance in work exhaustion, $20 \%$ of the 
variance in organizational commitment, and $34 \%$ of the variance in turnover intention. Among the control variables, the only significant influence was from raises to turnover intention $(\beta=-.10, p<.05)$. Overall, we found support for the proposed model within this context. Hypotheses $1-6,9,10$, and 11 were all supported.

\begin{tabular}{|c|c|c|c|c|c|c|c|}
\hline \multicolumn{8}{|c|}{ Table 4. Factor Analysis } \\
\hline & \multicolumn{7}{|c|}{ Component } \\
\hline & 1 & 2 & 3 & 4 & 5 & 6 & 7 \\
\hline Turnover_1R & & & & .736 & & & \\
\hline Turnover_2 & & & & .875 & & & \\
\hline Turnover_3R & & & & .827 & & & \\
\hline Turnover_4 & & & & .883 & & & \\
\hline Exhaust_1 & & .814 & & & & & \\
\hline Exhaust_2 & & .853 & & & & & \\
\hline Exhaust_3 & & .728 & & & & & \\
\hline Exhaust_4 & & .693 & & & & & \\
\hline Fairness_1 & & & & & & & .883 \\
\hline Fairness_2 & & & & & & & .897 \\
\hline Fairness_3 & & & & & & & .708 \\
\hline Fairness_4 & & & & & & & \\
\hline Workload_1 & & & & & & .671 & \\
\hline Workload_2 & & & & & & .680 & \\
\hline Autonomy_1 & & & & & .907 & & \\
\hline Autonomy_2 & & & & & .913 & & \\
\hline Autonomy_3 & & & & & .892 & & \\
\hline Autonomy_4 & & & & & .856 & & \\
\hline WFC_2 & .629 & & & & & & \\
\hline WFC_3 & .819 & & & & & & \\
\hline WFC_4 & .833 & & & & & & \\
\hline WFC_5 & .777 & & & & & & \\
\hline WFC_6 & .796 & & & & & & \\
\hline WFC_7 & .847 & & & & & & \\
\hline WFC_8 & .842 & & & & & & \\
\hline OrgCom_3 & & & .786 & & & & \\
\hline OrgCom_4 & & & .888 & & & & \\
\hline OrgCom_5 & & & .857 & & & & \\
\hline OrgCom_6 & & & .794 & & & & \\
\hline OrgCom_7 & & & .754 & & & & \\
\hline
\end{tabular}




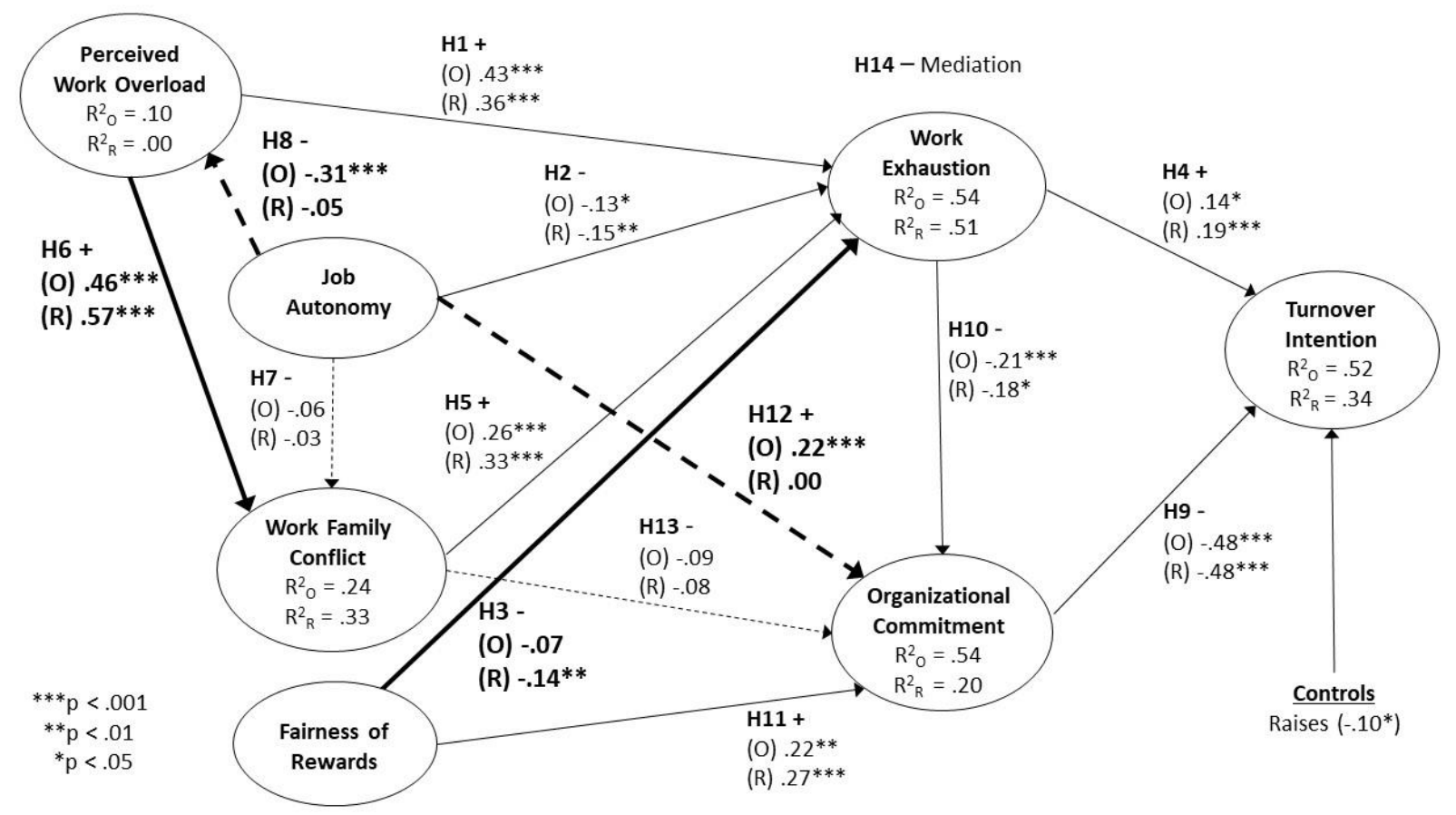

Figure 2. Hypotheses and Results of the Original Study (O) and Replication Study (R)

Notes: Bold lines and font highlight differences between the findings of the original and replication studies.

Dashed lines are non-significant relationships in replication study. Small dashed lines indicate consistent results for the original and replication studies while large dashed lines indicate different results between the two.

Hypotheses 7, 8, 12 and 13 were not supported (indicated with dashed lines in Figure 2). Consistent with the original study, job autonomy did not significantly influence work-family conflict $(\mathrm{H} 7 \mathrm{~ns})$. The variables in the model explained $0 \%$ of the variance in perceived work overload, which is consistent with the fact that there was only one predictor, job autonomy, which did not significantly influence perceived work overload (H8 ns). Job autonomy also did not influence organizational commitment for our replication (H12 ns).

To confirm mediation by organizational commitment and work exhaustion $(\mathrm{H} 14)$, we added direct paths to TOI from job autonomy, work-family conflict, work overload, and fairness of rewards, and re-ran the analysis. Fairness of rewards was the only additional significant predictor of TOI $(\beta=-0.139, p<.05)$. We then used the Sobel z-test (Sobel, 1982) to examine the significance of the direct and indirect effects following Cohen (1988) and Chin, Marcolin and Newsted (2003). Work exhaustion mediated the effects of perceived work overload (Sobel $Z=2.59, p<0.01$ ), work-family conflict (Sobel $Z=2.54, p<0.05$ ), and fairness of rewards (Sobel $Z=2.04, p<0.05$ ) on TOI. Organizational commitment mediated the effect of fairness of rewards (Sobel $Z=4.04, p<0.001$ ) on TOI. Together these results indicate full mediation of perceived work overload and work-family conflict through work exhaustion, partial mediation of fairness of rewards through work exhaustion and organizational commitment, and no influence (direct or indirect) of job autonomy on TOI. The results of the hypotheses are summarized in Table 5. 


\begin{tabular}{|c|c|c|c|}
\hline \multicolumn{4}{|c|}{ Table 5. Hypotheses Replicated } \\
\hline H\# & Hypothesis & $\begin{array}{l}\text { Original } \\
\text { Result }\end{array}$ & $\begin{array}{l}\text { Replication } \\
\text { Result }\end{array}$ \\
\hline $\mathrm{H} 1$ & $\begin{array}{l}\text { Perceived work overload will positively influence work } \\
\text { exhaustion among IT Road Warriors. }\end{array}$ & Supported & Supported \\
\hline $\mathrm{H} 2$ & $\begin{array}{l}\text { Autonomy will negatively influence work exhaustion } \\
\text { among IT Road Warriors. }\end{array}$ & Supported & Supported \\
\hline H3 & $\begin{array}{l}\text { Fairness of rewards will negatively influence work } \\
\text { exhaustion among IT Road Warriors. }\end{array}$ & Not Supported & Supported \\
\hline $\mathrm{H} 4$ & $\begin{array}{l}\text { Work exhaustion will positively influence turnover } \\
\text { intention among IT Road Warriors. }\end{array}$ & Supported & Supported \\
\hline H5 & $\begin{array}{l}\text { Work-family conflict will positively influence work } \\
\text { exhaustion among IT Road Warriors. }\end{array}$ & Supported & Supported \\
\hline $\mathrm{H} 6$ & $\begin{array}{l}\text { Perceived work overload will positively influence work- } \\
\text { family conflict among IT Road Warriors. }\end{array}$ & Supported & Supported \\
\hline $\mathrm{H} 7$ & $\begin{array}{l}\text { Job autonomy will negatively influence work-family } \\
\text { conflict among IT Road Warriors. }\end{array}$ & Not Supported & Not Supported \\
\hline H8 & $\begin{array}{l}\text { Autonomy will negatively influence perceived work } \\
\text { overload among IT Road Warriors. }\end{array}$ & Supported & Not Supported \\
\hline H9 & $\begin{array}{l}\text { Organizational commitment will negatively influence } \\
\text { turnover intention among IT Road Warriors. }\end{array}$ & Supported & Supported \\
\hline $\mathrm{H} 10$ & $\begin{array}{l}\text { Work exhaustion will negatively influence } \\
\text { organizational commitment among IT Road Warriors. }\end{array}$ & Supported & Supported \\
\hline $\mathrm{H} 11$ & $\begin{array}{l}\text { Fairness of rewards will positively influence } \\
\text { organizational commitment among IT Road Warriors. }\end{array}$ & Supported & Supported \\
\hline $\mathrm{H} 12$ & $\begin{array}{l}\text { Job autonomy will positively influence organizational } \\
\text { commitment among IT Road Warriors. }\end{array}$ & Supported & Not Supported \\
\hline $\mathrm{H} 13$ & $\begin{array}{l}\text { Work-family conflict will negatively influence } \\
\text { organizational commitment among IT Road Warriors. }\end{array}$ & Not Supported & Not Supported \\
\hline $\mathrm{H} 14$ & $\begin{array}{l}\text { Work exhaustion and organizational commitment will } \\
\text { fully mediate the effects of job autonomy, perceived } \\
\text { work overload, work-family conflict, and fairness of } \\
\text { rewards on turnover intention among IT Road Warriors. }\end{array}$ & Supported & $\begin{array}{l}\text { Partially } \\
\text { Supported }\end{array}$ \\
\hline
\end{tabular}

\section{Discussion}

Results from the replication study revealed mixed support for the original study's findings. Consistent with Ahuja et al. (2007) the relationships between work exhaustion, organizational commitment, and turnover intention were supported, thus confirming their generalizability. The influence of work-family conflict on work exhaustion but not on organizational commitment was consistent with the relationships found in the original study in both strength and direction. Interestingly, while the influence of the specific antecedents did not follow the same pattern, in both the original and replication studies the amount of variance explained for the work exhaustion construct was similar $\left(r^{2}=.54\right.$ for original and $r^{2}=.51$ for replication).

The replication study also revealed a few potentially non-generalizable constructs and relationships. In contrast to the original study, the replication study found that fairness of rewards played a much larger role 
in the model for in-house IT professionals than autonomy. Considering the statistical difference between the number of raises in the original study and the replication, this is quite interesting. Those participants in the replication study did not receive as many raises as those in the original study. This may be a potential explanation for why the fairness of rewards was more salient and played a larger role in the replication study than in the original study. In the original study job autonomy significantly influenced perceived work overload $\left(\beta_{0}=-.31 \mathrm{p}<.001\right)$, whereas in the replication study the relationship was non-significant. Additionally, in the original study job autonomy significantly influenced organizational commitment $\left(\beta_{\circ}=.22 p<.001\right)$, but in the current study the relationship was non-significant. Taken together, these findings indicate that the only role job autonomy played in the replication study was a small (but significant) negative relationship with work exhaustion. Thus, the profound influence of autonomy within the IT Road Warrior context was not replicable in the in-house IT context. In contrast, in the original study fairness of rewards did not significantly influence work exhaustion, but in the replication study it did ( $\beta_{O}=-.07$ ns versus $\beta_{R}=-.14 p<.01$ ). Thus, while the influence could not be categorized as strong, for in-house IT professionals perceptions of fairness seem to reduce work exhaustion, but not so for IT Road Warriors.

One explanation for these findings may be that the influence of job autonomy and fairness of rewards are context dependent. Previous research has asserted that autonomy is a job focused characteristic, whereas fairness of rewards is a workplace focused characteristic (McKnight et al., 2009). Our findings seem to support this categorization. Since IT Road Warriors spend the majority of their time at client firms (Madden, 1995), one would expect that job characteristics might have more of an influence on their level of work exhaustion. In the same light, as the in-house IT professionals in this study spend the majority of their time at the corporate headquarters of their employer, one would expect that workplace characteristics might have more of an influence on their level of work exhaustion. 'Embeddedness' is comprised of the forces that keep a person from leaving his or her job/organization/occupation (e.g., Mitchell, Homtom, Lee, Sablyski \& Erez, 2001; Yao, Lee, Mitchell, Burton, \& Sablynski, 2004). The nature of being a remote worker would emphasize the job tasks and being among others at headquarters would shift the perception of the job as embedded more in the social structure. Future research replicating this model may benefit from the inclusion of a qualitative component to better understand the job and workplace specific factors within the IT field. Interviews or focus groups with IT professionals could assist in teasing out and understanding the role of job-specific versus workplace-specific factors.

From a practitioner perspective, Morganson, Major, Oborn, Verive, and Heelan (2010) suggest that organizations should take action to improve the workplace inclusion of employees who work away from the main office by encouraging social contact with co-workers and work teams to make an effort to meet faceto-face on a regular basis. Within the IT literature, Windeler, Chudoba, and Sundrup (2017) suggest that IT professionals who participate in part-time telework can minimize some of the negative effects of full-time telework. This is particularly valuable for less experienced workers. Managers may need to devote special effort to engage client-based workers as they may benefit from focused work-life balance initiatives, stress management activities, and/or time away from the client location.

Another explanation may be the difference in measurement items used in the two studies. For example, the replication study used a conceptualization of job autonomy as "input in decision making"; whereas the original study used a measure of job autonomy "how, when and what work is done" (p. 8). This may indicate that different facets/dimensions of job autonomy are more or less relevant for different IT populations. Future research might incorporate expanded measures of job autonomy to determine if different dimensions (e.g., method, criteria, or schedule autonomy; Breaugh, 1985) are more or less relevant for different job types.

Additionally, in the replication study perceived work overload was less influential on work exhaustion $\left(\beta_{R}=\right.$ $.36 p<.001$ versus $\left.\beta_{0}=.43 p<.001\right)$, but more influential on work-family conflict than the original study $\left(\beta_{R}\right.$ $=.57 \mathrm{p}<.001$ versus $\beta_{0}=.46 p<.001$ ). Because the IT employees in this replication study were not IT Road Warriors, the perceived work overload could have been more influential on work-family conflict because they were 'at home' and could have experienced work-family balance issues on a more regular basis. Participation in family commitments would probably not even be a possibility for the IT Road Warriors when they were physically in a different geographic locale. In contrast, in-house IT professionals may face more work-family balance issues as participation in family commitments may be more of a choice.

When considering alternate or flexible work arrangements one can look at modes of work (e.g., mobile, home-based telecommuting, satellite office) as well as scheduling of work (e.g., telework, flex time, part time) (Messenger \& Gschwind, 2016). Alternate work arrangements often allow more control over the timing of activities, but the potential expansion and intensification of work hours can also become a source of stress when choices have to be made between tasks and responsibilities that coexist for work and home (Noonan 
\& Glass, 2012; Golden, 2012; Golden, Veiga, \& Simsek, 2006; Tietze \& Musson, 2005). In essence, the flexibility may reduce the impact of some stresses, but it may also introduce new ones. Especially in high stress jobs, working from home may increase the permeability of work and personal life domains, thus not allowing workers to mentally or physically escape work (Russell, O'Connell, \& McGinnity, 2009).

Family stage has been found to be influential in structuring a teleworkers daily life (Hilbrecht, Shaw, Johnson, \& Andrey, 2013). In addition, the highest quality personal/family hours may not always be outside the regular workday. Research has found that employees engaging in flexible work arrangements who perceived greater psychological job control had significantly lower TOI, family-work conflict, and depression (Kossek, Lautsch, \& Eaton, 2006). Thus, when considering alternate work arrangements, putting an individual's time to its best use, regardless of the hour, may translate into better work/family balance.

Finally, the amount of variance explained by the antecedents of organizational commitment and turnover intention was significantly lower in the replication study than in the original study (organizational commitment $\mathrm{r}^{2} \mathrm{R}=.20$ and $\mathrm{r}^{2} \mathrm{O}=.54 ; \mathrm{TOI} \mathrm{r}^{2} \mathrm{R}=.34$ and $\mathrm{r}^{2} \mathrm{O}=.52$ ). One likely explanation for this finding may be the lack of direct influence of job autonomy on organizational commitment and the indirect influence of job autonomy on turnover intention in the replication study. While job autonomy played a significant role in the model for IT Road Warriors, its influence appears to be contextual (i.e., moderator). In conjunction with the more limited role of job autonomy for in-house IT professionals, another related explanation may lie in the role of fairness of rewards. Individuals naturally tend to self-evaluate by comparing themselves and their situation to others that they can identify with (Festinger, 1954; Suls \& Wheeler, 2000) often using pay or performance as a benchmark for the comparison (e.g., Bloom \& Michel, 2002; Chen, Zhang, \& Latimer, 2014).

In-house IT employees are often subject to potentially detrimental influences in terms of social comparisons and perceived office politics. For example, in-house IT employees may see their poorer performing colleagues receiving more or larger raises, coveted promotions, or being assigned to better projects. In essence, they perceive that other workers are more successful, or scoring higher on the points of comparison, and the other's success is often attributed to office politics or a lack of managerial awareness. In-house IT employees get to see first-hand how their colleagues perform on a day-to-day basis. If the colleagues that they perceive to be poorly-performing being rewarded, they may perceive it as unfair. As such, their organizational commitment may be less, as their lower perceptions of fairness may directly and indirectly negatively influence organization commitment via increased work exhaustion.

In contrast, the IT Road Warrior could be characterized as a disinterested third party, who sees the dysfunctionality of the individuals and decision-making in the client organization but is not part of it. The IT Road Warrior has been brought into the client organization because of his/her expertise in a specific area (and the organization's lack of expertise in that area), and as such the organization allows the IT Road Warrior the flexibility and autonomy to complete the work as he/she sees fit. The IT Road Warrior assigned to a client organization directly observes the lack of fairness happening in the organization they are engaged with, but is grateful that he/she is not participating in the comparisons and can leave the work environment as soon as the engagement is completed. As such, the organizational commitment of the IT Road Warrior may be greater, as their perceptions of fairness only directly and positively influence organizational commitment.

Finally, it is possible that the influence of constructs outside the scope of the original study, such as the influence of boundary spanning activities or identity, may explain the differences. Previous research has hinted at the positive influence of boundary spanning on commitment (Baroudi, 1985) and the negative influence of boundary spanning on turnover intention (Igbaria \& Siegel, 1992). Researchers may find additional variance can be explained by incorporating constructs such as organizational and/or professional identity as recent research has indicated identity may play a role in IT professionals' turnover intentions (e.g., Brooks, Riemenschneider, Hardgrave, \& O'Leary-Kelly, 2011).

\subsection{Limitations and Future Research}

As researchers look to further replicate this model, there are three important limitations that must be noted. First, the replication study was conducted with IT professionals in a single organization. While this approach is consistent with the original study, this may have introduced some systematic bias into the results. Care should be taken in generalizing these results to other in-house IT professionals. Additionally, future research should measure organizations with multiple work arrangements (e.g., home, mobile, and office personnel) to see if the influence of work arrangement characteristics are drowned out by firm specific factors. Our second limitation is the composition of the sample, specifically that $50 \%$ of the respondents were male. The 
IT field is known to be predominately male (typical gender ratio is approximately $75 \%$ male). The uncertainty represented in our gender composition of this sample (i.e., $40 \%$ non-response to the gender question) may have affected the results, and care should be taken when generalizing across the IT field. A third limitation is that there may be some degree of variable confounding in the sense that some workers may choose (and others not) whether to engage in alternate work arrangements such that there may be some self-selection that correlates with the antecedents. Future research should capture the level of voluntariness of the participants' work arrangement. Controlling for self-selection bias would be helpful in evaluating the overall impact of alternate work arrangements on IT professionals.

Our limitations notwithstanding, we see three primary avenues for future research that may be fruitful. First, given the disparity in findings between the original study and the replication study, future research should explore the influence of job autonomy and fairness of rewards on turnover intentions in other IT work contexts. For example, this model could be tested across industries, organizations, and employee types (e.g., temporary workers). Second, future research should investigate Ahuja et al.'s (2007) model of turnover intention for various sub-populations within the IT profession, such as system administrators, contract workers, project managers, and perhaps ClOs. By looking at various job functions and contexts, the generalizability of this model and boundary conditions could be further elaborated. Finally, researchers may want to explore additional measures for the constructs within the model such as fairness and autonomy, to either confirm or refute the conceptual boundaries.

\section{Conclusion}

This research sought to replicate the study presented by Ahuja et al. (2007) on the exhaustion and turnover intention of IT Road Warriors. We largely validated the model proposed in the original study through a conceptual replication, and found support for the relationships between exhaustion, organizational commitment, and turnover intention. The contextual and measurement discrepancies found in the results of the replication study highlights the generalizable (e.g., work exhaustion - turnover intention) and nongeneralizable (e.g., job autonomy - organizational commitment) relationships presented in the original study. In contrast to the original study, the replication study found that fairness of rewards was much more important to in-house IT professionals than job autonomy. 


\section{References}

Adams, G. A., King, L. A., \& King, D. W. (1996). Relationships of job and family involvement, family social support, and work-family conflict with job and life satisfaction. Journal of Applied Psychology, 81(4), 411-420.

Ahuja, M. K., Chudoba, K. M., Kacmar, C. J., McKnight, D. H., \& George, J. F. (2007). ICT road warriors: Balancing work-family conflict, job autonomy, and work overload to mitigate turnover intentions. MIS Quarterly, 31(1), 1-17.

Armstrong, J. S., \& Overton, T. S. (1977). Estimating nonresponse bias in mail surveys. Journal of Marketing Research, 14(3), 396-402.

Baroudi, J. J. (1985). The impact of role variables on IS personnel work attitudes and intentions. MIS Quarterly, 9(4), 341-356.

Beehr, T. (1976). Perceived situational moderators of the relationship between subjective role ambiguity and role strain. Journal of Applied Psychology, 61(1), 35-40.

Bloom M., \& Michel, J. G. (2002). The relationships among organizational context, pay dispersion, and among managerial turnover. Academy of Management Journal, 45(1), 33-42.

Brooks, N. G., Riemenschneider, C. K., Hardgrave, B. C., \& O'Leary-Kelly, A. M. (2011). IT professional identity: Needs, perceptions, and belonging. European Journal of Information Systems, 20(1), 87102.

Breaugh, J. A. (1985). The measurement of work autonomy. Human Relations, 38(6), 551-570.

Chen, F., Zhang, L., \& Latimer, J. (2014). How much has my co-worker contributed? The impact of anonymity and feedback on social loafing in asynchronous virtual collaboration. International Journal of Information Management, 34(5), 652-659.

Chin, W. W. (1998). The partial least squares approach to structural equation modeling. In G. A. Marcoulides (Ed.), Modern methods for business research (pp. 295-336). Mahwah, NJ: Lawrence Erlbaum Associates, Inc.

Chin, W. W. (2001). PLS-Graph user's guide. Houston, TX: University of Houston, CT Bauer College of Business.

Chin, W. W., Marcolin, B. L., \& Newstead, P. R. (2003). A partial least squares latent variable modeling approach for measuring interaction effects: Results from a Monte Carlo simulation study and an electronic-mail emotion/adoption study. Information Systems Research, 14(2), 189-217.

Cohen, J. (1988). Statistical power analysis for the behavioral sciences, 2nd ed. Hillsdale, NJ: Lawrence Erlbaum.

Cropanzano, R., Rupp, D., \& Byrne, Z. (2003). The relationship of emotional exhaustion to work attitudes, job performance, and organizational citizenship behaviors. Journal of Applied Psychology, 88(1), 160169.

Festinger, L. (1954). Theory of social comparison processes. Human Relations, 7(2), 117-140.

Fornell, C., \& Larcker, D. F. (1981). Evaluating structural equation models with unobservable variables and measurement error. Journal of Marketing Research, 18(3), 39-50.

Golden, T. D. (2012). Altering the effects of work and family conflict on exhaustion: Telework during traditional and nontraditional work hours. Journal of Business and Psychology, 27(3), 255-269.

Golden, T. D., Veiga, J. F., \& Simsek, Z. (2006). Telecommuting's differential impact on work-family conflict: Is there no place like home? Journal of Applied Psychology, 91(6), 1340-1350.

Hackman, J., \& Oldham, G. (1975). Development of the job diagnostic survey. Journal of Applied Psychology, 60(2), 159-170.

Hilbrecht, M., Shaw, S. M., Johnson, L. C., \& Andrey, J. (2013). Remixing work, family and leisure: Teleworkers' experiences of everyday life. New Technology, Work, and Employment, 28(2), 130-144. 
Igbaria, M., \& Greenhaus, J. H. (1992). Determinants of MIS employees' turnover intentions: A structural equation model. Communication of the ACM, 35(2), 35-49.

Igbaria, M., \& Siegel, S. (1992). The reasons for turnover of information systems personnel. Information \& Management, 23(4), 321-330.

Kossek, E. E., Lautsch, B. A., \& Eaton, S. C. (2006). Telecommuting, control, and boundary management: Correlates of policy use and practice, job control, and work-family effectiveness. Journal of Vocational Behavior, 68(2), 347-367.

Lin, S.-L., \& Hsieh, A-T. (2002). Constraints of task identity on organizational commitment. International Journal of Manpower, 23(2), 151-165.

Lindell, M. K., \& Whitney, D. J. (2001). Accounting for common method variance in cross-sectional research designs. Journal of Applied Psychology, 86(1), 114.

Lo, J. (2014). New perspectives on staff turnover in the IT field. HEC Knowledge. Retrieved on June 25, 2017, from URL http://www.hec.edu/Knowledge/Strategy-Management/Human-ResourcesManagement/New-Perspectives-on-Staff-Turnover-in-the-IT-Field.

Luftman, J., \& Kempaiah, M. R. (2007). The IS organization of the future: The IT talent challenge. Information Systems Management, 24(2), 129-138.

Madden, J. (1995, October). Road warriors. American Demographics, pp. 4-9.

McKnight, D. H., Phillips, B., \& Hardgrave, W. C. (2009). Which reduces IT turnover intention the mostworkplace characteristics or job characteristics? Information \& Management, 46(3), 167-174.

Messenger, J. C., \& Gschwind, L. (2016). Three generations of telework: New ICTs and the (r)evolution from home office to virtual office. New Technology, Work and Employment, 31(3), 195-208.

Mitchell, T. R., Holtom, B. C., Lee, T. W., Sablynski, C. J., \& Erez, M. (2001). Why people stay: Using job embeddedness to predict voluntary turnover. Academy of Management Journal, 44(8), 1102-1121.

Moore, J. E. (2000). One road to turnover: An examination of work exhaustion in technology professionals. MIS Quarterly, 24(1), 141-168.

Morganson, V. J., Major, D. A., Oborn, K. L., Verive, J. M., \& Heelan, M. P. (2010). Comparing telework locations and traditional work arrangements: Differences in work-life balance support, job satisfaction, and inclusion. Journal of Managerial Psychology, 25(6), 578-595.

$\mathrm{Ng}, \mathrm{T}$. W. H, \& Feldman, D. C. (2010). The relationships of age with job attitudes: A meta-analysis. Personnel Psychology, 63(3), 677-718.

Noonan, M. C. \& Glass, J. L. (2012). The hard truth about telecommuting. Monthly Labor Review, 135(6), $38-45$.

Podsakoff, P. M., \& Organ, D. W. (1986). Self-reports in organizational research: Problems and prospects. Journal of Management, 12(4), 531-544.

Podsakoff, P. M., MacKenzie, S. B., Lee, J. Y., \& Podsakoff, N. P. (2003). Common method biases in behavioral research: A critical review of the literature and recommended remedies. Journal of Applied Psychology, 88(5), 879.

Purohit, M. (2016). A study on - employee turnover in IT sector with special emphasis on Wipro and Infosys. IOSR Journal of Business and Management, 18(4), 47-51.

Russell, H., O'Connell, P. J., \& McGinnity, F. (2009). The impact of flexible working arrangements on worklife conflict and work pressure in Ireland. Gender, Work \& Organization, 16(1), 73-97.

Sobel, M. E. (1982). Asymptotic confidence intervals for indirect effects in structural equation models. Sociological Methodology, 13, 290-312.

Suls, J., \& Wheeler, L. (2000). Handbook of Social Comparison: Theory and Research. New York: Plenum Press.

Thomas, L. T., \& Ganster, D. C. (1995). Impact of family-supportive work variables on work-family conflict and strain: A control perspective. Journal of Applied Psychology, 80(1), 6-15. 
Tietze, S., \& Musson, G. (2005). Recasting the home-work relationship: A case of mutual adjustment? Organization Studies, 26(9), 1331-1352.

Tsui, A., Pearce, J. L., Porter, L. W., \& Tripoli, A. M. (1997). Alternative approaches to the employeeorganization relationship: Does investment in employees pay off? Academy of Management Journal, 40(5), 1089-1121.

Wayne, S. J., Shore, L. M., \& Liden, R. C. (1997). Perceived organizational support and leader-member exchange: A social exchange perspective. Academy of Management Journal, 40(1), 82-111.

Widaman, K. (1985). Hierarchical nested covariance structure models for multitrait-multimethod data. Applied Psychological Measurement, 9(1), 1-26.

Williams, L., Cote, J., \& Buckley, M. (1989). Lack of method variance in self-reported affect and perceptions of work: Reality or artifact? Journal of Applied Psychology, 74(3), 462-468.

Windeler, J. B., Chudoba, K. M., \& Sundrup, R. Z. (2017). Getting away from them all: Managing exhaustion from social interaction with telework. Journal of Organizational Behavior, 38(7), 977-995.

Yao, X., Lee, T. W., Mitchell, T. R., Burton, J. P., \& Sablynski, C. S. (2004). Job embeddedness: Current research and future directions. In R. Griffeth and P. Hom (Eds.), Understanding Employee Retention and Turnover (pp. 153-187). Greenwich, CT: Information Age. 


\section{Appendix A: Methodological Details}

\begin{tabular}{|c|c|c|}
\hline & & Table A1. Constructs and Items \\
\hline Construct & Variables & Items \\
\hline \multirow{7}{*}{$\begin{array}{l}\text { Affective } \\
\text { Organizational } \\
\text { Commitment }^{c}\end{array}$} & OrgCom $1^{*}$ & $\begin{array}{l}\text { I am willing to put in a great deal of effort beyond that } \\
\text { normally expected in order to help this organization be } \\
\text { successful. }\end{array}$ \\
\hline & OrgCom2* $^{*}$ & I really care about the fate of this organization. \\
\hline & OrgCom3 & $\begin{array}{l}\text { I am extremely glad that I chose this organization for which } \\
\text { to work, over other organizations I was considering at the } \\
\text { time I joined. }\end{array}$ \\
\hline & OrgCom4 & $\begin{array}{l}\text { I talk up employment in this organization to friends as a } \\
\text { great place to work. }\end{array}$ \\
\hline & OrgCom5 & I am proud to tell others that I work for this organization. \\
\hline & OrgCom6 & $\begin{array}{l}\text { I find that my values and this organization's values are very } \\
\text { similar. }\end{array}$ \\
\hline & OrgCom7 & $\begin{array}{l}\text { For me this is the best of all possible organizations for } \\
\text { which to work. }\end{array}$ \\
\hline \multirow{4}{*}{ Autonomyc } & Aut1 & $\begin{array}{l}\text { In my work, I usually do not have to refer matters to my } \\
\text { direct supervisor for a final decision. }\end{array}$ \\
\hline & Aut2 & $\begin{array}{l}\text { Usually, my direct supervisor does not have to approve my } \\
\text { decisions before I can take action. }\end{array}$ \\
\hline & Aut3 & $\begin{array}{l}\text { Rather than asking my direct supervisor, I usually make my } \\
\text { own decisions about what to do on my job. }\end{array}$ \\
\hline & Aut4 & $\begin{array}{l}\text { I can usually do what I want on this job without consulting } \\
\text { my direct supervisor. }\end{array}$ \\
\hline \multirow{5}{*}{$\begin{array}{l}\text { Fairness of } \\
\text { Rewards }\end{array}$} & Fair1 & I think my level of pay is fair. \\
\hline & Fair2 & Overall, the rewards I receive here are quite fair. \\
\hline & Fair3 & $\begin{array}{l}\text { No matter what other group members do on joint } \\
\text { assignments, I believe my efforts will be rewarded fairly. }\end{array}$ \\
\hline & Fair4 & $\begin{array}{l}\text { I'm comfortable that I would never be penalized because a } \\
\text { co-worker failed to do his/her part of a joint assignment. }\end{array}$ \\
\hline & Fair5 $^{*}$ & $\begin{array}{l}\text { Sometimes I fear that my performance evaluation will } \\
\text { unfairly suffer because a co-worker didn't do her/his part. } \\
\text { ( R ) }\end{array}$ \\
\hline \multicolumn{3}{|l|}{ * Dropped items } \\
\hline $\begin{array}{l}\text { Scales: } \\
\text { a } 7 \text { pt Likert s } \\
\text { b } 7 \text { pt Likert s } \\
\text { c } 7 \text { pt Likert s } \\
\text { d } 7 \text { pt Likert s }\end{array}$ & $\begin{array}{l}\text { ale, Very Unl } \\
\text { ale, Never-D } \\
\text { ale, Strongly } \\
\text { ale, Daily-On }\end{array}$ & $\begin{array}{l}\text { ly-Very Likely } \\
\text { sagree-Strongly Agree } \\
\text { a year or less }\end{array}$ \\
\hline
\end{tabular}




\begin{tabular}{|c|c|c|}
\hline \multicolumn{3}{|c|}{ Table A1. Constructs and Items - Continued } \\
\hline Construct & Variables & Items \\
\hline \multirow{8}{*}{$\begin{array}{l}\text { Work-family } \\
\text { Conflict }^{\mathrm{c}}\end{array}$} & WFC1* & My work schedule often conflicts with my family life. \\
\hline & WFC2 & $\begin{array}{l}\text { After work, I come home too tired to do some of the things } \\
\text { l'd like to do. }\end{array}$ \\
\hline & WFC3 & $\begin{array}{l}\text { On the job I have so much work to do that it takes away } \\
\text { from my personal interests. }\end{array}$ \\
\hline & WFC4 & $\begin{array}{l}\text { My family dislikes how often I am preoccupied with my work } \\
\text { while I am home. }\end{array}$ \\
\hline & WFC5 & $\begin{array}{l}\text { Because my work is demanding, at times I am irritable at } \\
\text { home. }\end{array}$ \\
\hline & WFC6 & $\begin{array}{l}\text { The demands of my job make it difficult to be relaxed all the } \\
\text { time at home. }\end{array}$ \\
\hline & WFC7 & My work takes up time that l'd like to spend with my family. \\
\hline & WFC8 & $\begin{array}{l}\text { My job makes it difficult to be the kind of spouse or parent } \\
\text { l'd like to be. }\end{array}$ \\
\hline \multirow{2}{*}{$\begin{array}{l}\text { Perceived } \\
\text { Work } \\
\text { Overloadd }\end{array}$} & PW1 & I feel busy or rushed. ( R ) \\
\hline & PW2 & I feel pressured. ( R ) \\
\hline \multirow{4}{*}{$\begin{array}{l}\text { Turnover } \\
\text { Intention }\end{array}$} & TOl1 & I will be with this company five years from now. ( R ) \\
\hline & TOI2 & $\begin{array}{l}\text { I will probably look for a job at a different company in the } \\
\text { next year. }\end{array}$ \\
\hline & TOI3 & $\begin{array}{l}\text { How likely is it that you will be working at the same } \\
\text { company this time next year? }(R)\end{array}$ \\
\hline & TOI4 & $\begin{array}{l}\text { How likely is it that you will take steps during the next year } \\
\text { to secure a job at a different company? }\end{array}$ \\
\hline \multirow{4}{*}{$\begin{array}{l}\text { Work } \\
\text { Exhaustion }\end{array}$} & WE1 & I feel emotionally drained from my work. \\
\hline & WE2 & I feel used up at the end of the work day. \\
\hline & WE3 & $\begin{array}{l}\text { I feel fatigued when I get up in the morning and have to } \\
\text { face another day on the job. }\end{array}$ \\
\hline & WE4 & I feel burned out from my work. \\
\hline \multirow{6}{*}{ Demographics } & D1_Raises & $\begin{array}{l}\text { How many base pay increases have you had over the past } \\
\text { five years, if any? }\end{array}$ \\
\hline & D2_OrgTenure & How long have you worked at this company? \\
\hline & D3_Income & What is your annual income for this job? \\
\hline & D5_JobTenure & How long have you had this job? \\
\hline & D9_Gender & Gender: \\
\hline & D10_Race & What is your ethnicity/race? \\
\hline
\end{tabular}


Table A2. Common Method Variance Test

\begin{tabular}{|c|c|c|c|c|c|}
\hline Construct & Indicator & $\begin{array}{l}\text { Substantive } \\
\text { Construct } \\
\text { Correlation }\end{array}$ & $\begin{array}{l}\text { Substantive } \\
\text { Construct } \\
\text { Variance } \\
\text { Explained }\end{array}$ & $\begin{array}{l}\text { Common- } \\
\text { method } \\
\text { Factor } \\
\text { Correlation }\end{array}$ & $\begin{array}{l}\text { Common- } \\
\text { method } \\
\text { Variance } \\
\text { Explained }\end{array}$ \\
\hline \multirow{4}{*}{ Autonomy } & AUT1 & 0.91 & 0.83 & 0.06 & 0.00 \\
\hline & AUT2 & 0.93 & 0.86 & 0.09 & 0.01 \\
\hline & AUT3 & 0.66 & 0.44 & 0.01 & 0.00 \\
\hline & AUT4 & 0.63 & 0.40 & 0.02 & 0.00 \\
\hline \multirow{4}{*}{ Fairness } & FAIR1 & 0.51 & 0.26 & 0.12 & 0.01 \\
\hline & FAIR2 & 0.65 & 0.42 & 0.21 & 0.04 \\
\hline & FAIR3 & 0.79 & 0.62 & 0.12 & 0.01 \\
\hline & FAIR4 & 0.58 & 0.34 & 0.31 & 0.10 \\
\hline \multirow{3}{*}{$\begin{array}{l}\text { Organizational } \\
\text { Commitment }\end{array}$} & ORGCOM3 & 0.81 & 0.66 & 0.26 & 0.07 \\
\hline & ORGCOM4 & 0.66 & 0.44 & 0.43 & 0.18 \\
\hline & ORGCOM5 & 0.76 & 0.58 & 0.28 & 0.08 \\
\hline \multirow{2}{*}{$\begin{array}{l}\text { Perceived } \\
\text { Work } \\
\text { Overload }\end{array}$} & PW1 & 0.88 & 0.77 & 0.20 & 0.04 \\
\hline & PW2 & 0.91 & 0.83 & 0.29 & 0.08 \\
\hline \multirow{4}{*}{$\begin{array}{l}\text { Turnover } \\
\text { Intention }\end{array}$} & TOl1 & 0.67 & 0.45 & 0.19 & 0.04 \\
\hline & TOI2 & 0.84 & 0.71 & 0.24 & 0.06 \\
\hline & TOI3 & 0.74 & 0.55 & 0.17 & 0.03 \\
\hline & TOI4 & 0.88 & 0.77 & 0.27 & 0.07 \\
\hline \multirow{4}{*}{$\begin{array}{l}\text { Work } \\
\text { Exhaustion }\end{array}$} & WE1 & 0.79 & 0.62 & 0.10 & 0.01 \\
\hline & WE2 & 0.79 & 0.62 & 0.19 & 0.04 \\
\hline & WE3 & 0.79 & 0.62 & 0.16 & 0.03 \\
\hline & WE4 & 0.76 & 0.58 & 0.17 & 0.03 \\
\hline \multirow{6}{*}{$\begin{array}{l}\text { Work-Family } \\
\text { Conflict }\end{array}$} & WFC2 & 0.75 & 0.56 & 0.34 & 0.12 \\
\hline & WFC3 & 0.72 & 0.52 & 0.33 & 0.11 \\
\hline & WFC4 & 0.76 & 0.58 & 0.11 & 0.01 \\
\hline & WFC5 & 0.79 & 0.62 & 0.13 & 0.02 \\
\hline & WFC6 & 0.71 & 0.50 & 0.33 & 0.11 \\
\hline & WFC7 & 0.77 & 0.59 & 0.10 & 0.01 \\
\hline
\end{tabular}




\begin{tabular}{|c|c|c|c|c|c|c|}
\hline \multirow[b]{2}{*}{ Variable } & \multicolumn{3}{|c|}{ Original } & \multicolumn{3}{|c|}{ Replication } \\
\hline & Mean & Std & ICR & Mean & Std & ICR \\
\hline 1. Work-Family Conflict*** & 5.04 & 1.37 & 0.95 & 3.51 & 1.43 & 0.95 \\
\hline 2. Job Autonomy & 5.04 & 1.12 & 0.87 & 4.97 & 1.31 & 0.93 \\
\hline 3. Work Overload ${ }^{* \star *}$ & 4.10 & 1.46 & 0.94 & 4.55 & 1.52 & 0.94 \\
\hline 4. Work Exhaustion & 3.59 & 1.37 & 0.94 & 3.73 & 1.58 & 0.94 \\
\hline $\begin{array}{l}\text { 5. Organizational } \\
\text { Commitment }^{\star \star}\end{array}$ & 5.29 & 1.21 & 0.93 & 4.94 & 1.27 & 0.94 \\
\hline 6. Fairness of Rewards & 4.36 & 1.30 & 0.95 & 4.53 & 1.32 & 0.87 \\
\hline 7. Turnover Intention & 2.55 & 1.35 & 0.95 & 2.83 & 1.44 & 0.93 \\
\hline 8. Organizational Tenure ${ }^{\star * *}$ & 1.80 & 1.74 & 1.00 & 9.37 & 7.35 & 1.00 \\
\hline 9. Job Tenure & $\mathrm{n} / \mathrm{a}$ & $\mathrm{n} / \mathrm{a}$ & 1.00 & 3.13 & 4.44 & 1.00 \\
\hline 10. Gender & $\mathrm{n} / \mathrm{a}$ & $\mathrm{n} / \mathrm{a}$ & 1.00 & $\mathrm{n} / \mathrm{a}$ & $\mathrm{n} / \mathrm{a}$ & 1.00 \\
\hline 11. Number of Raises ${ }^{\star \star \star}$ & 4.69 & 1.86 & 1.00 & 1.45 & 1.87 & 1.00 \\
\hline
\end{tabular}

\begin{tabular}{|c|c|c|c|c|c|c|c|c|c|}
\hline \multicolumn{10}{|c|}{$\begin{array}{l}\text { Table A4. AVEs and Correlations among Latent Constructs } \\
\text { (Original Study and Replication Study) }\end{array}$} \\
\hline Variable & AVEO $^{\circ}$ & AVE $^{\mathrm{R}}$ & 1 & 2 & 3 & 4 & 5 & 6 & 7 \\
\hline $\begin{array}{l}\text { 1. Work-Family } \\
\text { Conflict }\end{array}$ & .79 & .73 & - & $-.20^{* *}$ & $.48^{* *}$ & $.52^{\star *}$ & $-.32^{* *}$ & $-.32^{\star *}$ & $.22^{* *}$ \\
\hline $\begin{array}{l}\text { 2. Job } \\
\text { Autonomy }\end{array}$ & .63 & .78 & -.03 & - & $-.31^{* *}$ & $-.34^{* \star}$ & $.55^{* *}$ & $.58^{\star *}$ & $-32^{* *}$ \\
\hline $\begin{array}{l}\text { 3. Work } \\
\text { Overload }\end{array}$ & .79 & .89 & $.57^{* *}$ & -.04 & - & $.65^{* *}$ & $-.41^{* *}$ & $-.33^{* *}$ & $.25^{\star *}$ \\
\hline $\begin{array}{l}\text { 4. Work } \\
\text { Exhaustion }\end{array}$ & .80 & .78 & $.60^{* *}$ & $-.17^{* *}$ & $.60^{* *}$ & - & $-.49^{* *}$ & $-.40^{* *}$ & $.42^{* *}$ \\
\hline $\begin{array}{l}5 . \\
\text { Organizational } \\
\text { Commitment }\end{array}$ & .76 & .75 & $-.30^{* *}$ & .05 & $-.16^{* *}$ & $-.34^{\star *}$ & - & $.60^{\star *}$ & $-67^{* *}$ \\
\hline $\begin{array}{l}\text { 6. Fairness of } \\
\text { Rewards }\end{array}$ & .80 & .63 & $-.38^{* *}$ & $.16^{* *}$ & $-.28^{* *}$ & $-.38^{* *}$ & $.33^{* *}$ & - & $.38^{* *}$ \\
\hline $\begin{array}{l}\text { 7. Turnover } \\
\text { Intention }\end{array}$ & .82 & .78 & $.20^{\star *}$ & $-.12^{*}$ & $.14^{*}$ & $.34^{* *}$ & $-.53^{* *}$ & $-.32^{* *}$ & - \\
\hline \multicolumn{10}{|c|}{$\mathrm{AVE}^{\mathrm{O}}$ is for the original study; $\mathrm{AVE}^{\mathrm{R}}$ is for the replication study. } \\
\hline
\end{tabular}




\section{About the Authors}

Deborah J. Armstrong. Deb is an Associate Professor of Management Information Systems in the College of Business at Florida State University. Her research is programmatic in its focus at the nexus of information systems (IS) - where people, process, and technology coalesce. Specifically, her research interests cover issues at the intersection of IS personnel and cognition, involving the human aspects of technology, change, and learning. Many of the research problems that Deb finds interesting involve gender-related IT workforce issues. Deb has published articles in such journals as MIS Quarterly, the Journal of Management Information Systems, the European Journal of Information Systems and Communications of the ACM. Deb would like to thank God for His many blessings.

Cynthia K. Riemenschneider. Cindy is Associate Dean for Research and Faculty Development and Professor of Information Systems in the Hankamer School of Business at Baylor University. She also holds the Helen Ligon Professorship in Information Systems. Her publications have appeared in MIS Quarterly, Information Systems Research, Journal of Management Information Systems, Information Systems Journal, European Journal of Information Systems, IEEE Transactions on Software Engineering, and others. She currently conducts research on IT work force issues, women and minorities in IT, IT professional turnover and turnaway intention as well as ethical issues surrounding IT use.

Mari W. Buche. Mari is an Associate Professor of Management Information Systems at Michigan Technological University (USA). She joined the faculty in August 2003 after earning her Ph.D. in Business Administration/Management Information Systems from the University of Kansas. She teaches both undergraduate and graduate courses in the School of Business \& Economics, and has received several teaching awards. Her research interests focus on issues related to the impact of technology change on employees within the business environment. Currently, her research involves improved decision making using "big data" business intelligence/analytical techniques. Mari's work has been published in high-quality journals and appears in numerous international conference proceedings.

Kenneth R. Armstrong. Ken is an Associate Teaching Faculty of Management Information Systems in the College of Business at Florida State University. Ken entered academia in 2001 after successful careers in control system sales, engineering, design and then software development. Since then he has won a plethora of teaching awards in both face-to-face and online formats. Ken has been invited to make several presentations on aspects of teaching excellence, and his work appears in numerous international conference proceedings.

Copyright @ 2018 by the Association for Information Systems. Permission to make digital or hard copies of all or part of this work for personal or classroom use is granted without fee provided that copies are not made or distributed for profit or commercial advantage and that copies bear this notice and full citation on the first page. Copyright for components of this work owned by others than the Association for Information Systems must be honored. Abstracting with credit is permitted. To copy otherwise, to republish, to post on servers, or to redistribute to lists requires prior specific permission and/or fee. Request permission to publish from: AIS Administrative Office, P.O. Box 2712 Atlanta, GA, 30301-2712 Attn: Reprints or via e-mail from ais@aisnet.org. 